\title{
The Impact of Micro Finance Factors on Women Entrepreneurs' Performance in Northern Sri Lanka
}

\author{
Rathiranee, Y. ${ }^{1} \&$ Semasinghe, S. D. ${ }^{2}$ \\ ${ }^{1}$ Senior Lecturer, Department of Financial Management, Univerisity of Jaffna, Sri Lanka. \\ ${ }^{2}$ Senior Lecturer, Department of Commerce \& Financial Management, University of Kelaniya, Sri Lanka. \\ Correspondence: Rathiranee, Y., Senior Lecturer, Department of Financial Management, University of Jaffna, Sri \\ Lanka.
}

Received: January 27, 2016

doi:10.11114/ijsss.v4i3.1422
Accepted: February 18, 2016

Available online: February 28, 2016

\begin{abstract}
Entrepreneurship development is an important tool to develop the individual and society as well as the country. Women play a vital role in the family and society as well. There is no evidence to the development of the country without considering women enhancement. Therefore, women are considering an important to develop the country. However they face challenges and difficulties in their day to day lives and social phenomenon. The government takes necessary action to improve their living condition and generating income opportunity in the developing countries and Sri Lanka as well. In the post war context Sri Lankan economy faces so many challenges specifically in women lives because women lost their male relatives and loves ones due to the war situation. Micro finance is considered as an important tool to enhance the women's living condition and generate income opportunity. However, it is found out that women entrepreneurs do not have easy access to micro finance factors for their entrepreneurial activity and as such have low business performance due to lack of infrastructure facilities. The objective of this study is to examine the impact of credit, savings and training on women entrepreneurs' performance in Northern Sri Lanka. Performance of the entrepreneurship is measured with the help of the variables of survival, growth and income /profit. The study involves a survey using structured questionnaire and in depth interviews to solicit responses from women entrepreneurs. Data analysis involves the use of SPSS software package to find out the impact of microfinance factors on business performance. The study concluded that there is an impact of credit and training on income / profit other than survival and growth. It was suggested that the monitoring and skill training facilities are essential to the survival and growth of the business.
\end{abstract}

Keywords: Micro finance, Credit, Saving, Women Entrepreneurs and Performance.

\section{Introduction}

Women are the key instrument in the society and their role is very important for the development of the world. They make a significant contribution not only to the family but also to the society. Entrepreneurship development is an important phenomenon to develop the society as well as the country. In order to develop the entrepreneurial activity the social capital and human capital are essential. Micro finance factors have vital role to enhance the business activities. And also it assists the poor women in eliminate the poor situation. Sri Lanka has introduced micro credit programmes targeted to the poor in the post war context. The thirty years civil war ended in 2009 left women single and widowed and they are marginalized by their families in Sri Lanka.

Micro Finance Institutions (MFIs) have vital role among the poorest people to increase their income in developing countries. The poorest people are the vulnerable people who are living in poverty and unhygienic condition without nutrition. MFIs play an important role against the poverty by assisting poor people to increase their wealth (Zama, 2004, cited by Haq, Hoque, and Pathan, 2008).The MFIs are empowering the poor people by providing financial and non-financial services to enhance their living standard through the facilities for poverty alleviation, health nutrition, education and self-employment opportunities and helping to get capital and independent income and contribute economically to their family and society. According to the State of Micro Credit Summit Campaign Report (2005), 3200 MFIs reached more than 92 million clients in 2004, of which around $73 \%$ were living in poverty when they provided the first loan to them. 
Support of thousands of microfinance customers in Sri Lanka reveals that access to financial services facilitates poor people to boost their household income, make assets, and cut their vulnerability. According to the report of Dirk Steinwand \& Bartocha (2008) microfinance is an adaptable supporter that affords them to remake their lives, plan for their future and their children and empower them with self-esteem and confidence.The impacts of microfinance are a combination in most cases where one impact leads to another. For instance, improved income is used for enhancement of the family or children, education \& health nutrition etc.Microcredit is the extension of small loans to those in poverty designed to encourage self-employment. The term microfinance usually entails very small loans to low-income clients for self-employment who lack access to traditional banking services. Microcredit is part of microfinance, which has been originated with the Grameen Bank from Bangladesh. In Bangladesh, microfinance has enabled poor people to employ in self-employment projects and allow them to create income and begin to rigid prosperity and exit poverty. According to Bagati (2003) many micro credit programs give a role to women in the economy and it will translate into positive changes in their status, empowering women like a 'magic wand'.

Microcredit is a tool for socioeconomic development. The United Nations (UN) declared 2005 the International Year of Microcredit (Delfiner, Pailhe and Peron, 2006).Though, Grameen Bank lend both men and women at equal rates initially, presently women became ninety-five percent of the bank's clients.Seventy-five percent of the microcredit recipients are women in worldwide (Ibid, 2006).From 1980s, other than lending to women who have higher repayment rates, and accepts smaller loans than men. Further, many microcredit institutions have used the goal of empowering women to justify their disproportionate loans to women.

Self-employed people refer to a person who works for them, however getting income from a business that they operate personally (en.wikipedia.org). Self-employment and women in entrepreneurship have been growing in developed economies for women to survive themselves and to help support their families (Gordon, 2000). Therefore it can be seen that women entrepreneurship is a growing phenomenon and has had a significant economic impact in all economies. However, women-owned enterprises have challenges and constraints that need to be addressed and specific needs that have to be identified to help them. Therefore, it is worth to investigate on women entrepreneurship performance and micro finance factors and examine to what extent the micro finance factors influence on their business performance in Northern Sri Lanka.

\section{Research Problem}

Micro finance factors influence on women entrepreneurs development but there is no sustainability and growth. Micro finance increases the income generating opportunity of the women but there is no evidence for their survival and growth of the businesses.Lack of capital to start or run business led them to request for credits from micro-finance institutions (Ibru, 2009; Kuzilwa, 2005). This is due to poverty, unemployment, low household and business income and inability to save (May, 2007; Otero, 1999; Porter \& Nagarajan, 2005; Roomi\& Parrot, 2008). Women entrepreneurs, mostly in developing countries, lack the ability to save (Akanji, 2006; Mkpado \& Arene, 2007), yet savings are needed to protect income, act as a security for loan and could be re-invested in the business (Akanji, 2006). In Sri Lanka specially in Northern part of Sri Lanka women face challenges and difficulties to enhance their business activity. The research problem is arisen as the following research question:

Whether the micro finance factors influence on women entrepreneurs' performance in Northern Province of Sri Lanka?

\section{Research Objectives}

The main objective of this research is;

To investigate the impact of micro finance factors on women entrepreneurs' performance.

The following sub objectives also have been derived from the main objective;

i. To identify the relationship between micro finance factors and women entrepreneurs' performance

ii. To find out the problems and challenges facing by the women entrepreneurs when they access micro finance.

iii. To suggest the ways to enhance the business performance of the women entrepreneurs.

\section{Literature Review}

Women entrepreneurs do not have easy access to credit for their entrepreneurial activity in developing countries (Ibru, 2009; Iganiga, 2008; Iheduru, 2002; Kuzilwa, 2005; Lakwo,2007; May, 2007; Okpukpara, 2009).They need credits to start or run their business activity due to lack of capital (Ibru, 2009; Kuzilwa, 2005). Women entrepreneurs, have no ability to save for their future needs in developing countries (Akanji, 2006; Mkpado\&Arene, 2007).Women entrepreneurs have lack of training facilities in developing countries. It is essential for developing human capital as well as providing learning opportunity for individuals to improve their skills, attitudes and efforts (Brana, 2008; Cheston \& 
Kuhn, 2002; Shane, 2003).

Training is a very important micro-finance factor as it would provide the skills and experience needed for their business activity (Akanji, 2006, Cheston \& Kuhn, 2002; Kuzilwa, 2005).

Literature confirmed that skill training and education have positive impact on entrepreneurial performance (Akanji, 2006; Cheston \& Kuhn, 2002; Kuzilwa, 2005). Most of the women entrepreneurs have lack of opportunity in this regard mostly in developing countries (Ibru, 2009).

Most of the studies are about the relationship between one or a combination of credit, savings andtraining, and women entrepreneurs' performance (e.g Akanji, 2006; Cheston \& Kuhn, 2002; Kuzilwa, 2005; Lawal et al., 2009; Olomola, 2002; Reavley \& Lituchy, 2008) but there is a little bit research that links credit, savings and training to women entrepreneurs' performance in developing countries, Sri Lanka inclusive. Women entrepreneurs in this context lack of credit, savings and training for their business activity and their business performance (Akanji, 2006; Cheston \& Kuhn, 2002; Ibru, 2009; Kuzilwa, 2005; Olomola, 2002).

However, micro-finance factors could not lead to business performance without opportunity providing for entrepreneurial activity. Financial management theorists believe that funds only could be caused to finance a pre-determined project, business activity or contract deal (Van Horne, 1980). So, micro-finance can lead to business performance only when there is the propensity to hold in new business activity or business extension (Antoncic, 2006; Shane, 2003).

Micro-finance factors and enterprise performance is vital to Northern Sri Lanka as the development is going on in this region under the post war development. In the light of this, the government has encouraged the vulnerable women to initiate entrepreneurial activities and form Women Societies, as groups, in order to access microfinance factors for their business activities or improvements. Such activities would serve as a tool for improving their living standard in particular and economy of the society in general.

Evidences from literature show that adequate credit leads to entrepreneurship performance (Gatewood et al., 2004; Kuzilwa, 2005; Martin, 1999; Ojo, 2009). Micro credit opportunity to women entrepreneurs is noticed in enhanced income, output, investment, employment and welfare of the entrepreneurs (Kuzilwa, 2005; Martin, 1999). Credit had positive impact on entrepreneurial performance in Kenya. Credit and savings had positive impact on business performance in Nigeria (Ojo, 2009). Credit and training had positive impact on women entrepreneur's performance in Tanzania (Kuzilwa, 2005). Savings have positive impact on enterprise productivity in Nigeria (Ojo, 2009). Credit, savings and training were found to have positive impact on women entrepreneurs' income and wellbeing in Haiti, Kenya, Malawi and Nigeria (UNCDF/UNDP, 2003). Savings and credit was also found to have positive effect on women entrepreneurs' wellbeing in Bangladesh, Indonesia, Ghana and Mexico (Vonderlack \& Schreiner, 2001).

\section{Hypotheses Development}

The following hypotheses have been developed as per the above problem and objectives:

$\mathrm{H}_{1}$ Micro credit, Savings and training are positively related to entrepreneurial performance in Northern Sri Lanka.

$\mathrm{H}_{1 \mathrm{a}}$ There is a strong impact of micro credit on business performance.

$\mathrm{H}_{1 \mathrm{~b}}$ Savings of women entrepreneurs lead to business performance.

$\mathrm{H}_{1 \mathrm{c}}$ Higher opportunity of skill training is one of the ways to improve the women entrepreneurship performance.

\section{Data Presentation and Analysis:}

\subsection{Descriptive statistics}

To give a better understanding of the micro entrepreneurs we delineate some core features of our data. Table 1 provides the summary statistics of the variables employed in this study, and shows a standard correlation matrix. The average mean of the variables is 3 and 4 except 2 for growth.

Table 1.Descriptive Statistics

\begin{tabular}{lrrrrr}
\hline & $\mathrm{N}$ & Minimum & Maximum & Mean & Std. Deviation \\
\hline Micro credit & 337 & 2.00 & 5.00 & 3.7300 & .83884 \\
Savings & 337 & 1.50 & 5.00 & 3.9095 & .61174 \\
Training & 337 & 2.00 & 5.00 & 4.2448 & .54671 \\
Sustainability & 337 & 1.00 & 5.00 & 4.3294 & .69851 \\
Growth & 337 & 1.00 & 5.00 & 2.0223 & .81550 \\
\hline
\end{tabular}




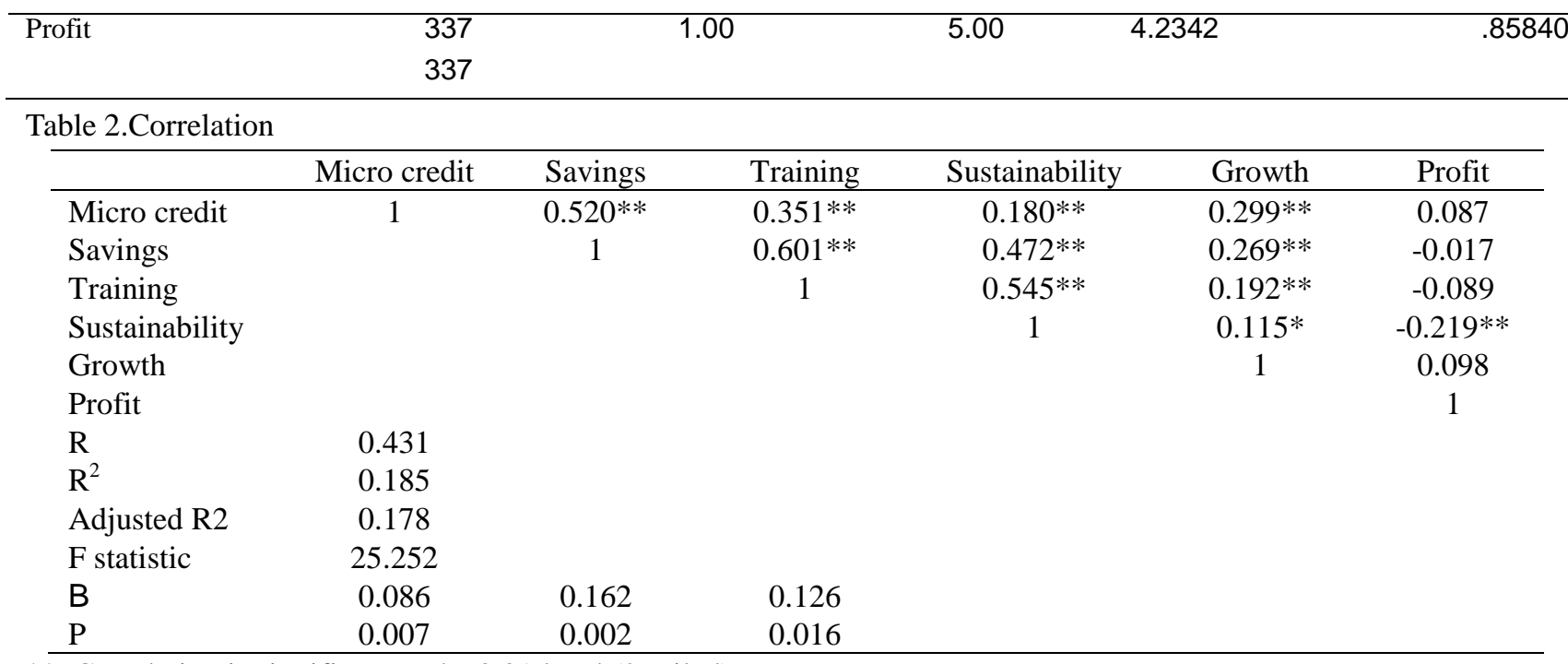

**. Correlation is significant at the 0.01 level (2-tailed).

\subsection{Relationship between Micro finance factors and Performance}

The regression analysis is used to find out the relationship / impact of Micro credit on women entrepreneurship performance. The table 2 shows that there is a relationship between micro credit and performance. There is a weak relationship between microcredit and variables of performance. However, there is a moderate relationship between savings and sustainability and Training and sustainability. It explains that the micro finance predicts only $18.5 \%$ on women entrepreneurship performance.

As per the table $1 \mathrm{H}_{1 \mathrm{a}}$ is rejected because significance $\mathrm{p}$ value is greater than 0.05 .Therefore, the statement 'There is a strong impact of micro credit on business performance" has been rejected. Further, $\mathrm{H}_{1 \mathrm{~b}}$ is accepted because significance $\mathrm{p}$ value is less than 0.05 .Therefore the statement "Savings of women entrepreneurs lead to business performance" is accepted. However, $\mathrm{H}_{1 \mathrm{c}}$ is rejected because significance $\mathrm{p}$ value is greater than 0.05 . The statement "Higher opportunity of skill training is one of the ways to improve the women entrepreneurship performance" is rejected.

The micro finance factors have no strong impact on business performance however it has an influence on it.In this study, only the micro credit, savings and training have been considered as micro finance factors. From the above discussion researchers can conclude that there is a positive relationship between micro finance factors and business performance. Savings plays a significant role in the business performance of women entrepreneurs in Northern Sri Lanka. But micro credit and training have low impact on business performance in Northern Sri Lanka. However, other factors such as education facilities, social awareness, advising regarding the usage of micro credit and other non-financial services, also have an impact on business performance. The micro credit loan facilities for self-employment, training facilities, health nutrition and poverty alleviation are not enough to enhance the performance of women in rural areas because of the other factors that have strong impact on that.According to Fletchner (2009) although the micro credit program has been initiated for the purpose of promoting micro enterprise development among poor women, the results of this study prove a meager access to micro credit does not enhance self employment of women. The intra-household dynamics improvement and the positive socio cultural environment are also required for enabling poor women to start the micro enterprises, owned and managed by them.

\section{Conclusion}

This study stipulates the importance of entrepreneurial performance. Business performance has posed a great challenge to the nations of the world, most especially the developing countries. Business performance enhancement is one of the vital issues of development where the poor women are expected to be supported to get them a good business performance. Therefore, government and non-governmental agencies are required to provide the resources or credit in order to assist the poor women to engage in business. Microfinance was established for this purpose to provide credit to the poor women to assist in empowering and subsequently, alleviating poverty. Training of women micro entrepreneur is necessary and important in order to enhance performance. Further, poor/lack of self-motivation is a barrier to start the business due to credit burden and family commitments.

Finally, it is concluded that there is need to complement credit-delivery with social awareness raising, building confidence, education and proper skill training among women. Women need advice about how to utilize public, private, natural and other resources and services. Micro finance factors, thus, is not sufficient in enhancing the women 
entrepreneurial performance, but it is one of the very important ingredients with the non credit aspects in that process. However, literatures have lent a strong support to the fact that training exerts much more influence on women micro entrepreneurs' performance than those who do not have training. This study is a proposed hypothesis for future study.

In order to lessen the problems and overcome the challenges, this study makes the following recommendations for the consideration of the policy makers, the practitioners and the other stakeholders.

In the post war context the basic facilities should be provided to the poor people to enhance their poor performance. The government and other political parties have more responsibility on the poor people who are living in the post war context. They should pay more attention to improve the microfinance activities in the war affected areas and they have to support the micro finance sector to increase the amount of loan facility and to cut the interest rate and other non-financial activities which will be useful to the rehabilitation of the war affected areas in Sri Lanka.

Finally, by establishing an Entrepreneurship Development (ED) shell, the network can be established among MFIs and funding organizations, industrial departments, NGOs, higher institutions and other institutions in relation with entrepreneurship by creating an ED Shell physically in a place and online by creating a website to have a good relationship among the members of the above organizations. It is possible to avoid the doubts of the people regarding self-employment activities, creating awareness in loan facilities, education, record keeping, business registration, marketing strategies and skill training etc. Women entrepreneurs' networks are the major sources of knowledge about women entrepreneurship. This network helps to deliver lectures, printed material to communicate the technical knowledge in production, processing, procurement, management and marketing among the other women. This will motivate other rural women to engage in micro-entrepreneurship with the right support and they can reinforce their capacities through adding further to the family income and national productivity. It may be a flat form to bring the investment and technology from the world.

\section{References}

Akanji, O. O. (2006). Microfinance as a strategy for poverty reduction.Central Bank of Nigeria Economic and Financial Review, 39(4).

Antoncic, B. (2006). Impacts of diversification and corporate entrepreneurship strategy making on growth and profitability: A normative model. Journal of Enterprising Culture, 14(1), 49-63.

Bagati, D. (2003) 'Microcredit and Empowerment of Women', Journal of Social Work Research and Evaluation, 4(1) 19-35.

Brana, S. (2008). Microcredit in France: Does gender matter? 5th Annual Conference-Nice.International Journal of Business and Social Science, 1(2).

Cheston, S., \& Kuhn, L. (2002).Empowering women through microfinance.A case study of Sinapi Aba Trust, Ghana.USA: Opportunity International.

Delfiner, M., Pailhe, C., \& Peron, S. (2006). Microinance: An analysis of experience and alternative regulations, Regulatory Research and Planning Department at the Central Bank of Argentina (BCRA).

Dirk, S., \& David, B. (2008).How Microfinance Improves Life in Sri Lanka, PROMIS - Promotion of the Microfinance Sector, gtz, Ministry of Finance and Planning.

Fletchner, D. (2009). Rural women's access to credit: Market Imperfections and Intrahoushold dynamics. World Development, 37(3).

Gatewood, E. J., Brush, C. G., Carter, N. M., Greene, P. G., \& Hart, M. M. (2004).Women entrepreneurs, growth and implications for the classroom.USA: Coleman Foundation whitepaper series for the USAAssociation for Small Business and Entrepreneurship.

Gordon, D. (2000). 'Inequalities in income, wealth and standard of living', in C. Pantazis and D. Gordon(eds) Tackling inequalities: Where are we now and what can be done? Bristol.

Hoque, M., \& Itohara, Y. (2009). Women empowerment through participation in micro - credit programme: a case study from Bangladesh.Journal of Social Sciences, Science Publications, Gale.

Ibru, C. (2009). Growing microfinance through new technologies.Federal University of Technology, Akure, Nigeria.

Iganiga, B. O. (2008). Much ado about nothing: The case of the Nigerian microfinance policy measures, institutions and operations. Journal of Social Sciences, 17(2), 89-101.

Iheduru, N. G. (2002). Women entrepreneurship and development: The gendering of microfinance in Nigeria. 8th International Interdisplinary Congress on Women.Makerere University, Kampala, Uganda. 
Kuzilwa, J. (2005). The role of credit for small business success: A study of the National Entrepreneurship Development Fund in Tanzania, The Journal of Entrepreneurship, 14(2), 131-161.

Martin, T. G. (1999). Socio-economic impact of microenterprise credit in the informal sector of Managua,

May, N. (2007). Gender responsive entrepreneurial economy of Nigeria: Enabling women in a disabling environment. Journal of International Women's Studies, 9(1).

Mkpado, M., \& Arene, C. J. (2007).Effects of democratization of group administration on the sustainability of agricultural microcredit groups in Nigeria. International Journal of Rural Studies, 14(2), 1-9.

Ojo, O. (2009). Impact of microfinance on entrepreneurial development: The case of Nigeria. Faculty of Administration and Business, University of Bucharest, Romania.

Okpukpara, B. (2009). Microfinance paper wrap-up: Strategies for effective loan delivery to small scale enterprises in rural Nigeria. Journal of Development and Agricultural Economics, 1(2), 41-48.

Olomola, A. S. (2002). Social capital, microfinance group performance and poverty implications in Nigeria.

Otero, M. (1999).Bringing development back into microfinance.Latin America: ACCION International.

Porter, E. G., \& Nagarajan, K. V. (2005). Successful women entrepreneurs as pioneers: Results from a study conducted in Karaikudi, Tamil Nadu, India. Journal of Small Business and Entrepreneurship, 18(1), 39-52.

Reavley, M. A., \& Lituchy, T. R. (2008). Successful women entrepreneurs: A six-country analysis of selfreported determinants of success-more than just dollars and cents. International Journal ofEntrepreneurship and Small Business, 5(3-4), 272-296.

Roomi, M. A., \& Parrot, G. (2008).Barriers to development and progression of women entrepreneurs in Pakistan.The Journal of Entrepreneurship, 17(1), 59-72.

Shane, S. (2003). A general theory of entrepreneurship: The individual-opportunity nexus. UK: Edward Elgar.

State of Micro Credit Campaign Report, (2005). Sam Daley - Harris, Micro Credit Summit Campaign, Washington DC, USA

UNCDF/UNDP. (2003). Microfinance Program: Impact assessment (2003) based on case studies in Haiti,

VanHorne, J. C. (1980). Fundamentals of financial management (4th ed). Englewood Cliffs, N.J: Prentice- Hall Inc.

Vonderlack, R. M., \& Schreiner, M. (2001).Women, microfinance and savings: Lessons and proposals. Washington University, St. Louis, USA: Center for Social Development.

\section{(cc) EY}

This work is licensed under a Creative Commons Attribution 3.0 License. 